apuntesuniversitarios.upeu.edu.pe

Apuntes Universitarios, 2020: 10(4), octubre-diciembre

ISSN: 2304-0335 DOI:https://doi.org/10.17162/au.v10i4.505

\title{
Investigando el impacto de los cursos de prácticas y de los principios de emprendimiento en la intención emprendedora de los estudiantes de agricultura
}

\section{Investigating the impact of internship courses and entrepreneurship principles on the entrepreneurial intention of agricultural students}

\author{
Nazanin Baluchi ${ }^{1 \mathrm{a}}$, Hamed Chaharsoughi Amin ${ }^{2}$, Mohammad Bagher Arayesh ${ }^{3} \&$ \\ Marjan Vahedi ${ }^{4}$ \\ Islamic Azad University, Ilam, Iran ${ }^{1234}$ \\ (iD) Orcid ID: https://orcid.org/0000-0002-7259-3226 ${ }^{1}$ \\ Orcid ID: https://orcid.org/0000-0003-0157-3794 ${ }^{2}$ \\ Orcid ID: https://orcid.org/0000-0002-6716-7943 3 \\ Orcid ID: https://orcid.org/0000-0002-8311-4227 ${ }^{4}$
}

Recibido: 04 de enero de 2020

Aceptado: 12 de julio de 2020

\begin{abstract}
Resumen
El propósito de este estudio fue investigar el impacto de los cursos de pasantía y los fundamentos empresariales en la intención empresarial de los estudiantes de los centros educativos de ciencias aplicadas en el oeste de Irán. Esta investigación es en términos de grado de control y grado de control, campo y en términos de método de obtención de hechos y datos es tipo de encuesta y en términos de recopilación de datos, es causal-correlacional. La población estadística de este estudio fue de 388 estudiantes de cursos agrícolas y de pregrado en Centros de Educación en Ciencias Aplicadas en cuatro provincias occidentales de Irán (Ilam, Kermanshah, Lorestan y Kurdistán). Como la lista de estudiantes que han completado pasantías y cursos de emprendimiento está disponible, la muestra se seleccionó como una muestra completa y finalmente se devolvieron 250 cuestionarios. La herramienta de recolección de datos fue un cuestionario realizado por un investigador cuya validez de contenido fue confirmada por un panel de expertos y su confiabilidad fue confirmada por el alfa de Cronbach. Los resultados del modelado de ecuaciones estructurales (SEM) utilizando el software Amos24 mostraron que, según el modelo, en el caso estándar, el efecto del período de pasantía en la actitud hacia el comportamiento 0.08 , el control conductual percibido $0.05 \mathrm{y}$ las normas subjetivas 19 es 0 , que es débil a efecto medio. Además, en el caso estándar, el efecto de los fundamentos del emprendimiento en las actitudes hacia el comportamiento es de 0,56, el control del comportamiento percibido es de 0,56 y las normas subjetivas es de 0,45, que es un efecto de moderado a fuerte.
\end{abstract}

Palabras clave: Intención emprendedora, pasantía, fundamentos del emprendimiento, científico-práctico, ecuaciones estructurales. 


\section{Abstract}

The purpose of this study was to investigate the impact of internship courses and entrepreneurship fundamentals on the entrepreneurial intention of students of applied science educational centers in western Iran. This research is in terms of degree of control and degree of control, field and in terms of method of obtaining facts and data is survey type and in terms of data collection, is causal-correlational. The statistical population of this study was 388 students of agricultural and undergraduate courses in Applied Science Education Centers in four western provinces of Iran (Ilam, Kermanshah, Lorestan and Kurdistan). Since the list of students who have completed internship and entrepreneurship courses is available, so the sample was selected as a whole sample and finally 250 questionnaires were returned. The data collection tool was a researcher-made questionnaire whose content validity was confirmed by a panel of experts and its reliability was confirmed by Cronbach's alpha. The results of structural equation modeling (SEM) using Amos 24 software showed that based on the model, in the standard case, the effect of the internship period on attitude towards behavior 0.08 , perceived behavioral control 0.05 and subjective norms 19 Is 0 which is a weak to medium effect. Also, in the standard case, the effect of entrepreneurship fundamentals on attitudes toward behavior is 0.56 , perceived behavioral control is 0.56 and subjective norms is 0.45 which is a moderate to strong effect.

Keywords: Entrepreneurial intention, internship, entrepreneurship fundamentals, scientificpractical, structural equations

\section{Introduction}

Nowadays, only nine of our main points are being used in our country, but with increasing attention, in the two decades that we can see it. I have confronted the policymakers of these countries in great numbers, so that the decline and fall of some of them is in the midst of a crisis. In Tunisia, the creation of opportunities for the patient, especially the graduates of the hospital, and the patient, in other words, The main, primary and secondary positions in the field of security and development are presented (Tajiabadi, 2008). Also, the significant increase in unemployment among graduates of agriculture has become a major problem in the country (Ghasemi \& Asadi, 2010).

On the other hand, the student body lacked the individual skills and competence needed to set up its own business and thus created opportunities, opportunities, and opportunities for entrepreneurs. In the meantime, three of the key approaches that have been adopted by Higher Education policy makers and planners have been to provide internship courses and entrepreneurship fundamentals for agricultural disciplines at universities. These courses are offered at most universities, including the University of Applied Sciences, in line with the philosophy of the university, which is to teach students skills. Any educational experience combined with a job can be called "internship" and it is this combination that makes internship a unique tool for career exploration (Qasemi \& Asadi, 2010). The word internship refers to the word "intern" and is said to refer to a person who, while studying in higher education or immediately after graduation, solely for the purpose of gaining work experience and practical experience in an institution. Internships can be compulsory or 
optional for individuals, meaning that the intern sometimes has to go on to two or three university courses to pursue an internship or voluntarily work in an industrial or administrative unit—without wages (Moradi et al., 2012). The internship is an opportunity for students to become familiar with the workplace, which not only enhances their potential for future employment but also gives interns more choice in the tasks they are assigned to do so. Understand their interests and tendencies in different fields and evaluate the strengths and weaknesses of their work. If the university, through industry liaison offices, creates a sense of need for the student to enter the labor market to do what he/she is taught in theory, then the student would appreciate every second of his or her internship. Will know, because he feels the need. Such a student takes a great deal of time and energy and is determined to get ahead of others in order to find a decent job and succeed. In fact, students who, on the one hand, strengthen their academic background and prepare themselves on the practical and practical side, enter the job market easily and do not even work at low salaries (Moradi et al., 2012).

Applied science-education is one that focuses more on developing professional skills and applying science in the real workplace than paying attention to the fundamentals. Therefore, this study seeks to answer the question of whether internship courses and entrepreneurship fundamentals for agricultural students in applied-science university affect their entrepreneurial intention, but not a study that demonstrates this effect scientifically. At least in the country level, it has not been adequately addressed and this is an issue. The results of this study can also provide useful information on internships to programmers, officials and university staff. And in particular Ilam University of Applied Sciences, so that Develop comprehensive, strategic, and effective programs for internships and offer entrepreneurship fundamentals to agricultural students and other majors.

\section{Theoretical foundations and research background}

There are many models in the world of entrepreneurial intention by various experts. Following Shapiro's model, the theory of planned behavior $(1988,1991)$ was proposed by Ajen. In this model, attitudes toward entrepreneurship, subjective norms, and self-efficacy beliefs are predictors of intention to start a business (Moriano \& Gorgievski, 2007). Thus, entrepreneurial intention is influenced by attitudes toward entrepreneurship, subjective norms, and self-efficacy (perceptions of feasibility). The model of planned behavior describes entrepreneurial intentions by combining the two factors of the individual and the community in such a way that personal characteristics, backgrounds and skills influence the entrepreneurial intentions as much as the social environment (community support and values). Figure 1 illustrates Aegean's theory of planned behavior 


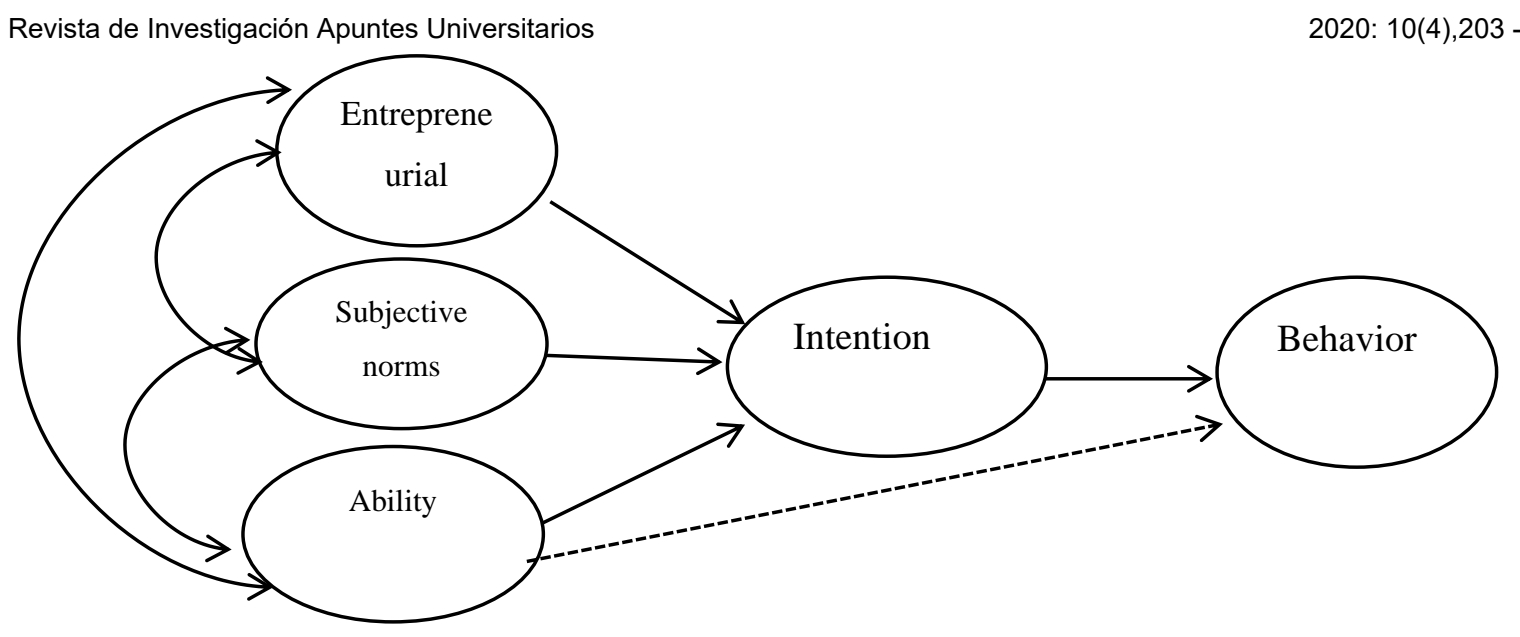

Figure 1: Agen's Theory of Planned Behavior

Many critics of the theory of planned behavior believe that this theory has introduced only one new variable. On the other hand, the evidence suggests that the greater the predictor power, the more variables it can enter. In this regard, Ajen (1991) stated that the theory of planned behavior is open to the introduction of new predictor variables. Although previous models are useful in research on intentions and entrepreneurial behavior, none of them have been used as a holistic model in such research. The limitations of these models are the nature of individualism and lack of attention to social factors. Therefore, the planned behavioral model of Agen (1991), due to the interaction between individual, social factors and the various factors in which they are used, has led to a greater interaction and interaction with the individual and environmental factors in society. It has been used as a valuable and powerful tool in examining entrepreneurial intentions and behavior. Also, according to the researchers, Agen's Theory of Planned Behavior (1991) provides a valid framework for analyzing and measuring how entrepreneurial behavior is explained by external and environmental factors. Extensive research has been done on entrepreneurial intention and its influencing factors, which are briefly discussed in the form of external and internal studies. Studies that have examined the impact of the internship period and the foundations of entrepreneurship on entrepreneurial intention are also mentioned.

According to Work and Employees (2014), there is a positive correlation between entrepreneurial self-efficacy and entrepreneurial self-efficacy. Martin et al. (2013) in their study found that entrepreneurial education has a positive impact on entrepreneurial knowledge, skills, perceptions, and outcomes, such as entrepreneurship. Therefore, it is to be expected that students who have passed the Entrepreneurial Education course will have subjective norms, attitude towards entrepreneurship, perceived behavioral control, and their entrepreneurial intention to pass the degree course. On the other hand, according to the findings of Julian (2013), emotional intelligence, mental perception of controlling behavior and attitude are important variables in predicting entrepreneurial intention. 
The results of a study by Ping et al. (2012) showed that subjective norms, entrepreneurial attitude, and entrepreneurial self-efficacy had a significant effect on students' entrepreneurial intention. According to the findings of Lee et al. (2011), self-efficacy is an important predictor of entrepreneurial intention and behavior. On the other hand, Aikulova et al. (2011) examine the entrepreneurial intention of students in the developing country and the developed country to use entrepreneurial intention model of planned behavior. The findings indicate that this model is applicable to both groups of developing and developed countries. In this regard, they generally reported that in each of the 13 countries surveyed, three factors were significantly associated with entrepreneurial intention. Lena et al. (2011) also believe that environmental and individual factors influence the level of entrepreneurship, and lack of a favorable work environment, motivation and purpose, are barriers to entrepreneurship.

The results of Moradi \& Delshad's (2017) study showed that there is a relationship between job training and apprenticeships with graduates' employment and entrepreneurship. The apprenticeship and apprenticeship courses should be justified in such a way that they can make the most of these courses. In their study, Hosseinien et al. (1986) concluded that six entrepreneurial skills are more important, which is planning, integrating and familiar with strong laws and regulations. Motivational work, challenge, marketing skills, and pragmatism are the most likely predictors of student entrepreneurial intent.

In a study, Karimi et al. (2016) concluded that the impact of entrepreneurship education on motivational factors (attitude, perceived behavioral control, subjective norms) and students' entrepreneurial intention were positive and significant. The results also showed that in the benefits program (learning, inspiration and growth resources), only learning had a positive and significant relationship with entrepreneurial attitude change and intention. Overall, the findings of this study indicate that "Theory of Planned Behavior" can provide a suitable framework for evaluating the effectiveness of entrepreneurship education programs.

On the other hand, the results of Shakiba et al. (2015) study showed that among the three dimensions of creativity considered in this study (individual creativity, students' perception of creativity in the academic and family environment), individual creativity is the only dimension that intends Entrepreneurship affects agricultural students and increases their entrepreneurial intention. However, the academic and family environment has not been able to foster creativity and thus promote entrepreneurship. The results of Karimi's study (2015) also showed that entrepreneurial attitude and perceived behavior control have a positive and significant relationship with entrepreneurial intention. Also, the results showed that the institutional environment is indirectly related to entrepreneurial intention through entrepreneurial attitude and perceived behavior control. In their study, Koshkaki et al. (2014) concluded that the weakness of support services and consulting, the inadequacy of applied training, the poor understanding of financial and management rules, and the weakness of 
educational programs were the most important. Obstacles to entrepreneurship education are in the scientific-practical centers of Fars province.

Keshavarz (2014) concluded in his study that entrepreneurial intentions of engineering, management and business students were significantly higher than those of other majors. In addition, public attitude, attitude toward entrepreneurship, belief in self-efficacy and entrepreneurship history are among the main factors influencing entrepreneurial intention of students of technical-engineering, management and business. However, the entrepreneurial intention of students in other disciplines can be explained by a general attitude, belief in selfefficacy and subjective social norms. The findings of Azizi \& Taheri's research (2013) showed that participation in entrepreneurship classes has increased the intention and tendency for entrepreneurship. In addition, participation in entrepreneurship classes has led to the improvement of some of the important psychological traits such as success, risk taking, and independence that are essential to entrepreneurship. However, the results of the Hosseini study (2013) showed that apprenticeship and internship courses do not have a significant impact on the development of entrepreneurial intention and the training of skilled and entrepreneurial staff. On the other hand, the results of a study by Baghersad et al. (2013) showed that entrepreneurship education influenced entrepreneurial intention and perception of technical and professional students' feasibility.

Since the theory of planned behavior is an important social cognitive theory that has been used in various contexts including individual and social to explain entrepreneurial behaviors (Krueger et al., 2000), therefore, the Aegean planned behavior model is used in this study as follows. Has been. In this model, the effect of internship course and entrepreneurship fundamentals on entrepreneurial intention of students of JAU is investigated.

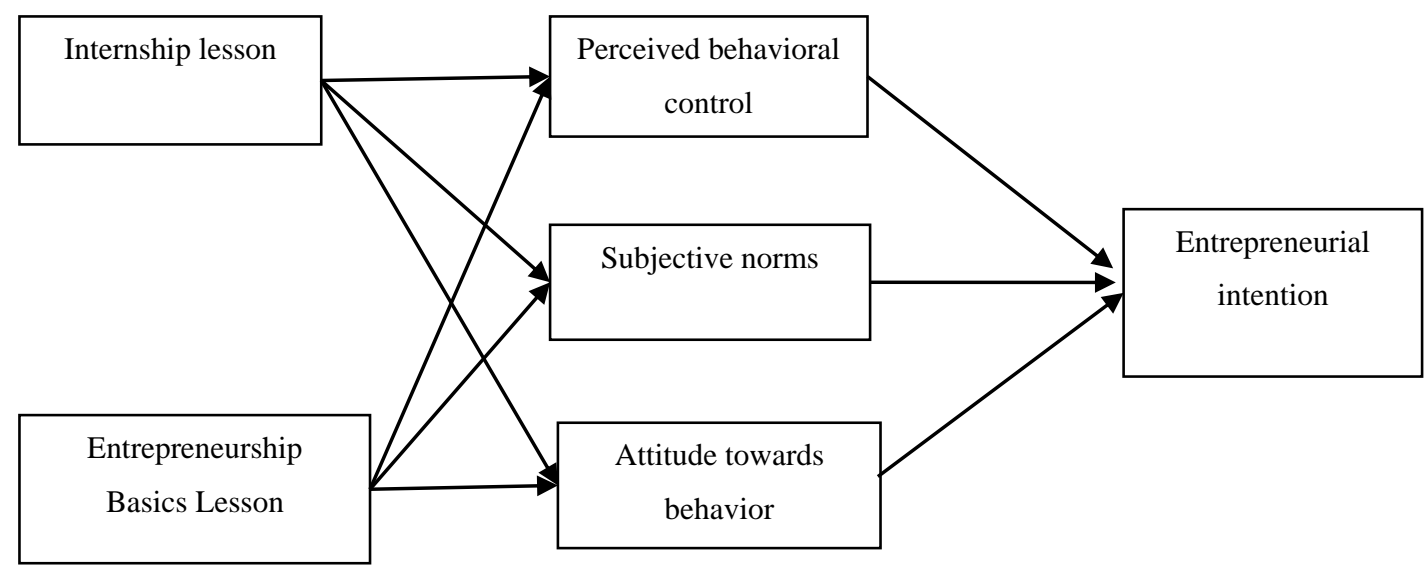

Figure 2. Conceptual Model of Research

\section{Research methodology}

This research is in terms of degree of control and degree of control, field and in terms of method of obtaining facts and data is survey type and in terms of data collection, is causalcorrelational. The statistical population of this study was 388 students of agricultural and 
undergraduate courses in Applied Science Education Centers in four western provinces of Iran (Ilam, Kermanshah, Lorestan and Kurdistan). Since the list of students who have completed internship and entrepreneurship courses is available, so the sample was selected as a whole sample and finally 250 questionnaires were returned.

The data collection tool in this study was a researcher-made questionnaire that was designed in accordance with the research objectives and study variables in several sections. Have been. Content validity (face validity) of this questionnaire was provided by a panel of experts (professors of extension and agricultural education of Ilam Islamic Azad University). The reliability of the questionnaire was measured by Cronbach's alpha. The results of Cronbach's alpha test show that the alpha value of the research variables is in good and acceptable level (Table 1).

\section{Table 1}

Cronbach's alpha for the variables under study

\begin{tabular}{cccc}
\hline Row & Segment or variable & Number of ítems & Cronbach's alpha value \\
\hline $\mathbf{1}$ & Entrepreneurial intention & 15 & 0.943 \\
$\mathbf{2}$ & Behavioral control perception is & 13 & 0.883 \\
$\mathbf{3}$ & Attitude towards behavior & 8 & 0.885 \\
$\mathbf{4}$ & Subjective norms & 8 & 0.898 \\
$\mathbf{5}$ & Internship period & 7 & 0.949 \\
$\mathbf{6}$ & Entrepreneurship Basics Lesson & 12 & 0.946 \\
\hline
\end{tabular}

In this study, the dependent variable is entrepreneurial intention and the variables of perceived behavioral control, subjective norms, and attitude to behavior are independent and their effect on entrepreneurial intention was measured. On the other hand, perceived behavioral control variables, subjective norms, and attitude toward entrepreneurial intention were dependent on the effect of internship variables and the course of entrepreneurship fundamentals on these variables. Descriptive statistics were used to describe the data. Frequency distribution tables, tendency indices and dispersion indices including mean, standard deviation and standard deviation were used.

Also, in the inferential statistics section, Pearson correlation test and then Structural Equation Modeling (SEM) were used. Structural equation modeling provides a coherent framework for estimating the power of relationships between all variables in a theoretical model. This model allows the researcher to test a set of regression equations simultaneously (Sharafi, 2014). In this study, a structural model was used to test the research hypotheses (evaluation of causal effects and the amount of explained variance) and a measurement model was used to show the relationships between hidden and explicit variables. Data analysis and data analysis was performed using SPSS25 and Amos24 software. 


\section{Research findings}

The results of descriptive statistics showed that the mean age of the subjects was 31.76 years, the oldest being 52 years and the youngest 18 years. The results also showed that most of the subjects $(92.8 \%)$ were in the $18-25$ age group and $71(28.4 \%)$ were in the 26-35 age group. The least studied were over 45 years of age. The results also showed that $150(60 \%)$ of the study subjects were associate degree and 100 (40\%) bachelor degree. According to the sample of the study population, 135 (54\%) of the subjects are single and 115 (46\%) are married. The results showed that $126(50.4 \%)$ of the subjects were unemployed and $124(49.6 \%)$ were employed, out of which 74 (59.6\%) were employees and 21 (16.93\%) Percent) have freelance jobs. The results showed that according to the sample selected from the statistical population of the study, 196 people (78.4\%) have no independent individual business and only 54 people have independent individual business experience. Of these, 4 (7.4\%) were in the agricultural business, 4 (7.4\%) were in the garment business and $3(5.55 \%)$ in the carpet weaving business. According to the results, 78 (31.2\%) of the subjects were high, $76(30.4 \%)$ were very high and $69(27.6 \%)$ were moderately inclined to earn money in the form of business. They have individual work.

\section{Table 2}

Describe the variables studied

\begin{tabular}{ccc}
\hline Variable & Abundance & Average \\
\hline Age & $\ldots \ldots \ldots \ldots \ldots \ldots$ & 76.31 \\
Level of Education & 150 people $(60 \%)$ associate \\
marital status & 100 patients $(40 \%)$ bachelor degree & \\
& 135 people $(54 \%$ single $)$ & \\
Employment status & 115 people $(46$ percent $)$ of married \\
Job Type & 126 patients $(4 / 50$ percent $)$ unemployed \\
& 124 people $(49.6 \%)$ employed \\
Independent business & 74 patients $(6 / 59$ percent $)$ employees \\
background & 21 patients $(93 / 16$ percent $)$ employed \\
& 6 people $(78.4 \%)$, no independent individual \\
Desire to start a business & business \\
& 54 has set up an independent business \\
& 78 people $(31.2 \%)$ had high inclination \\
\hline
\end{tabular}

\section{Test the data for normality}

The normality of the data distribution is one of the most important issues in selecting the type of statistics (parametric or non-parametric) and testing the hypotheses and this is why this study was conducted (Habibpour \& Shali, 2011: 408). In the present study, KolmogorovSmirnov test was used for normalization of variables. The result of this test indicates that all variables are normal (Table 3). 
Table 3

Kolmogorov - Smirnov test result to determine normal and abnormal distribution of studied variables

\section{Variable}

\section{Entrepreneurial intention}

Perceived behavioral control

Attitude towards behavior

Subjective norms

Internship period

Entrepreneurship Basics Lesson

\begin{tabular}{ccc}
\multicolumn{3}{c}{ Kolmogorov - Smirnov } \\
\hline Statistics & Significance level (Sig) & Result \\
\hline 1.061 & & \\
0.834 & 0.21 & normal distribution \\
0.377 & 0.49 & normal distribution \\
0.442 & 0.999 & normal distribution \\
1.127 & 0.99 & normal distribution \\
0.845 & 0.158 & normal distribution \\
& 0.473 & normal distribution \\
\hline
\end{tabular}

Source :Results of the survey

\section{Pearson correlation analysis results}

Since the variables of this study have a normal distribution, Pearson correlation coefficient was used to test the relationship between the variables of the study (Table 4). The results of correlation coefficient showed that there was a positive and significant relationship between internship course and perceived behavioral control variables, subjective norms, attitude toward behavior and entrepreneurial intention of students at one percent error level with 99 percent confidence. Also, there is a positive and significant relationship between entrepreneurship fundamentals course and perceived behavioral control variables, subjective norms, attitude towards students' entrepreneurial behavior and intention at one percent error level with 99 percent confidence.

\section{Table 4}

Correlation results of the research variables based on Pearson correlation

\begin{tabular}{cccc}
\hline The first variable & The second variable & Pearson & $\begin{array}{c}\text { Significant level } \\
\text { of restraint }\end{array}$ \\
\hline & Entrepreneurial intention & $0.441^{* *}$ & 0.000 \\
Internship & Perceived behavioral control & $0.331^{* *}$ & 0.000 \\
& Attitude towards behavior & $0.455^{* *}$ & 0.000 \\
& Subjective norms & $0.507^{* *}$ & 0.000 \\
Foundations of & Entrepreneurial intention & $0.571^{* *}$ & 0.000 \\
Entrepreneurship & Perceived behavioral control & $0.433^{* *}$ & 0.000 \\
& Attitude towards behavior & $0.563^{* *}$ & 0.000 \\
& Subjective norms & $0.529^{* *}$ & 0.000 \\
\hline
\end{tabular}

Source :Results of the study of meaning in with the $:^{* *}$ :significance of having a level of one percent :* significance of having a level of five percen

\section{Structural equations and the relationship between conceptual model variables}

Structural equation modeling (SEM) or multivariate analysis was used in this study. Structural equation modeling provides a coherent framework for estimating the power of relationships between all variables in a theoretical model. This model allows the researcher to 
test a set of regression equations simultaneously (Sharafi, 2014). The structural equation model used in this research is a general model (combination of measurement and structural model). The result of the measurement model is the confirmatory factor analysis that is used to confirm the model and the structural model is used to test the research hypotheses (evaluation of causal effects and explained variance). In fact, it is a structural model that shows how the main variables of the model influence or relate to each other. In this study, the causal relationships between the variables of the research model in the framework of structural equation modeling were estimated by AMOS software. The estimation results of the measurement model are presented in Table 5.

\section{Factor model of research in standard and non-standard modes}

In this section, the conceptual model of research and the results of the conceptual framework of research (Figure 2) are presented in the form of structural equation modeling using AMOS software. Structural equation models are a combination of factor analysis and path models.

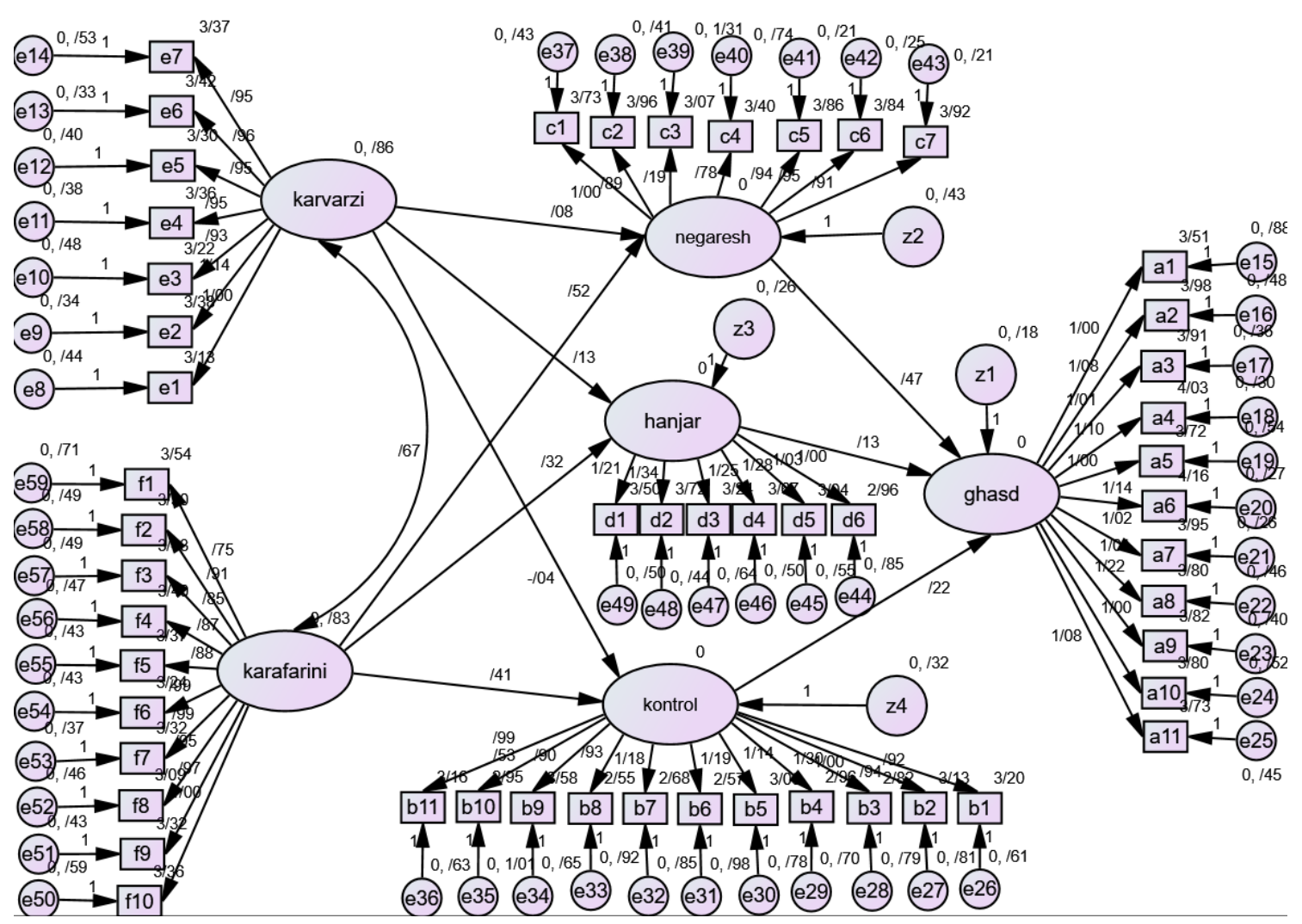

Figure (3). Factor model of research and path coefficients in nonstandard state 


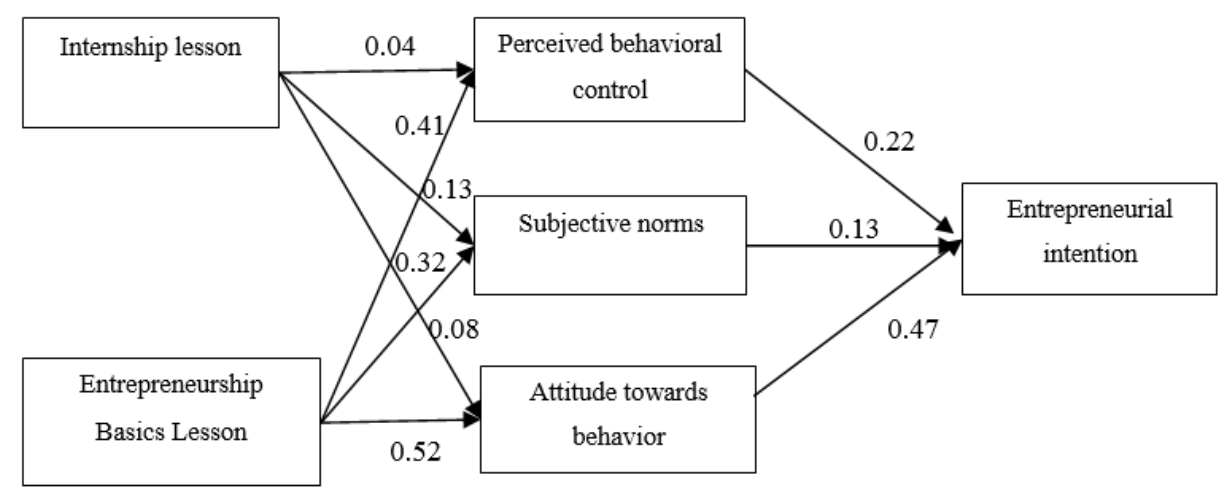

Figure (4). Structural model of research and path coefficients in nonstandard state

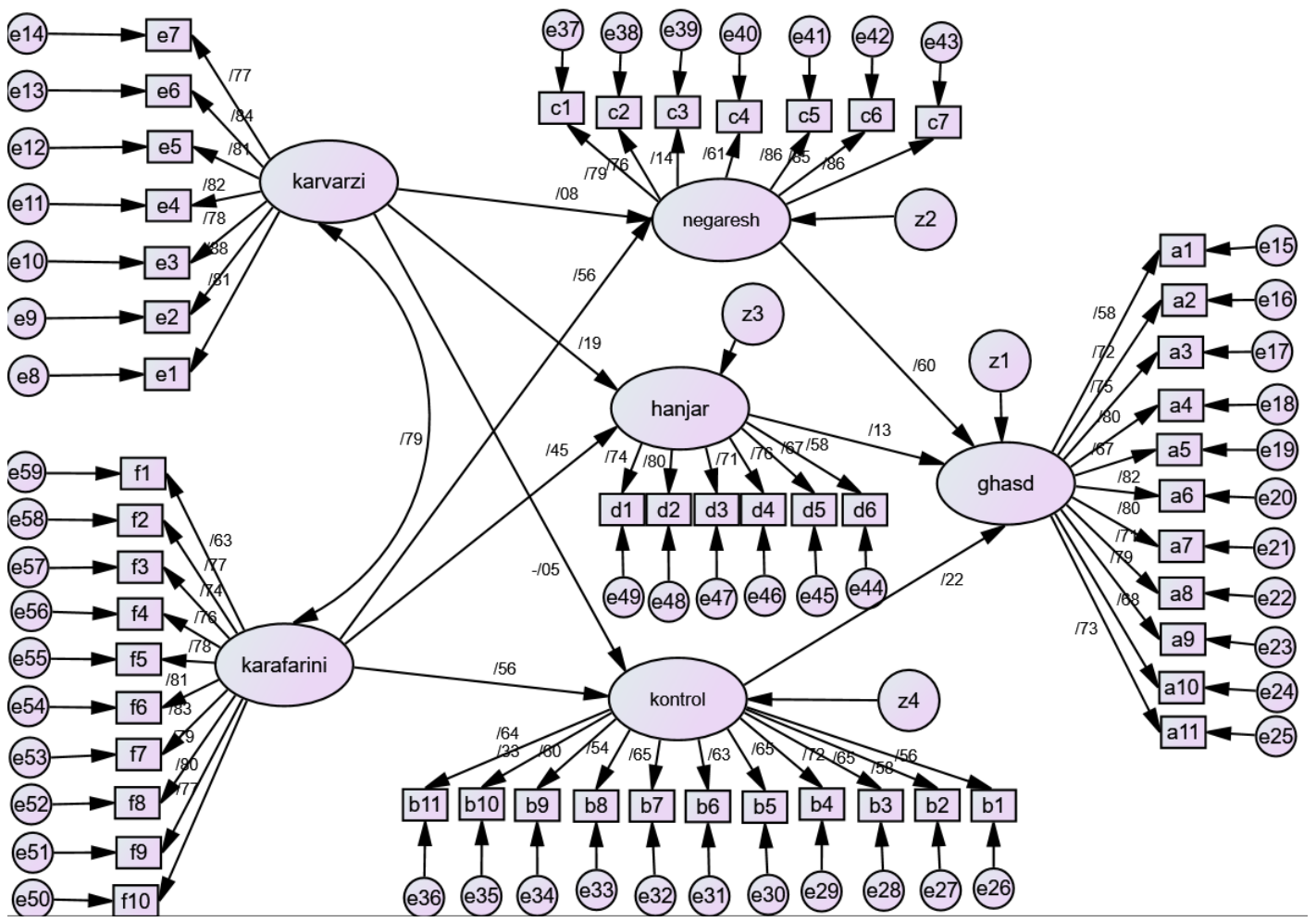

Figure (5). Standard Factor Research Model and Path Coefficients

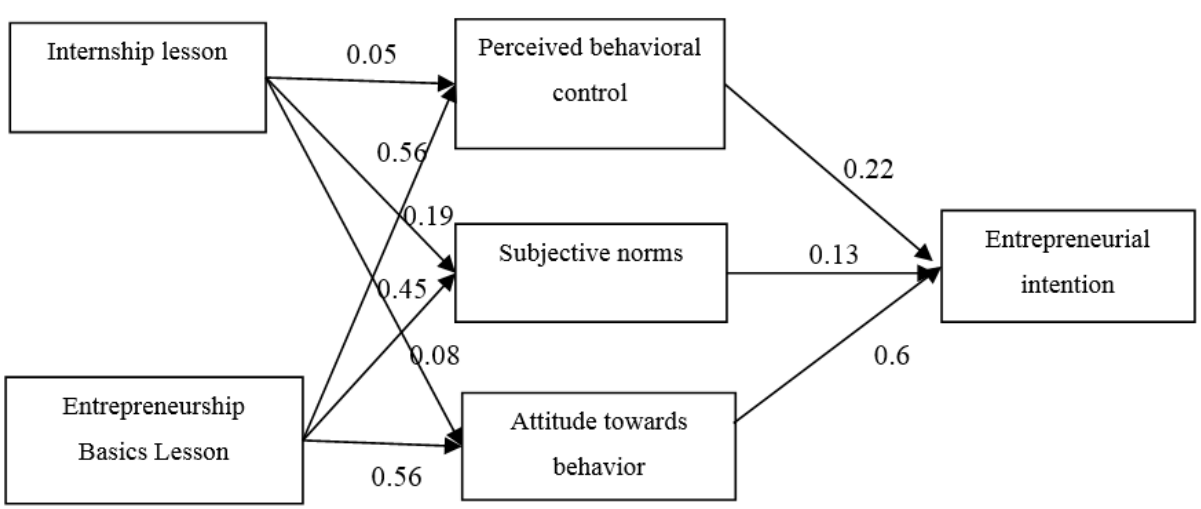

Figure (6). Structural Model of Research and Path Coefficients in Standard Mode 
The results show that in nonstandard and standard condition the effect of internship period on attitude towards behavior is 0.08 . In other words, if the effect of the other variables is assumed to be constant, by increasing one standard deviation in the internship period, there will be a 0.08 unit increase in attitude toward behavior. Thus, in both cases, the effect of the internship on attitudes toward behavior is a weak effect. Also, as the results show, in the nonstandard condition, the effect of the internship on perceived behavioral control was 0.04 and in the standard condition was 0.05 . Thus, in both cases, the effect of the internship period on perceived behavioral control is a weak effect. On the other hand, in nonstandard condition, the effect of internship on subjective norms is 0.13 and in standard condition is 0.19 . Therefore, in both cases the effect of the internship period on subjective norms is a moderate effect. The results show that in the nonstandard state the effect of entrepreneurship fundamentals on attitude towards behavior is 0.52 and in standard state is 0.56 .

Therefore, in both cases, the effect of entrepreneurship lessons on attitude toward behavior is a strong effect. Also, in the nonstandard state, the effect of entrepreneurship fundamentals on perceived behavioral control is 0.41 and in standard mode is 0.56 . Thus, in both cases, the effect of entrepreneurship lessons on perceived behavioral control is a strong effect. On the other hand, in the non-standard state, the effect of entrepreneurship lessons on subjective norms is 0.32 , and in standard mode, it is 0.45 . Thus, in both cases, the effect of entrepreneurship lessons on subjective norms is a moderate to strong effect. However, subjective norm variables (with a coefficient of 0.13 in nonstandard and 0.13 in standard mode) could not have a significant effect on entrepreneurial intention. The effect of attitude variable on entrepreneurial intention variable is in non-standard (0.47) and standard (0.60). Therefore, this variable has a strong effect in both cases and has had a great impact on entrepreneurial intention. Also, perceived behavioral control has had a moderate effect on entrepreneurial intention in both cases (non-standard coefficient 0.22 and standard coefficient $0.22)$.

\section{Investigation of model fit indices}

In general, there are several fitness indices for evaluating structural equation models. In this study, chi-square indices, comparative fit index, normalized fit index, and very important root mean square error index were used to evaluate the structural model. 
Table (5) models of Index

Fit index

\begin{tabular}{c}
\hline KaiScore (CMIN / DF) \\
CFI Adaptive Fit Index \\
IFI Incremental Fit Index \\
NFI Normalized fit index \\
PCFI Suitable fit index \\
RMSEA The second root of the mean squared error \\
estimation
\end{tabular}

Desirable criteria

$\begin{array}{cc}\leq 3 & 2 / 11 \\ \geq 0 / 9 & 0 / 912 \\ \geq 0 / 9 & 0 / 908 \\ \geq 0 / 9 & 0 / 923 \\ \geq 0 / 5 & 0 / 648 \\ \leq 0 / 08 & 0 / 068\end{array}$

One of the indicators of suitability of the model is the normal chi-square value (CMIN / DF), if it is less than 3, it indicates that the model fits well. Since this value is 2.11 in the present study, it indicates that the model is appropriate. Also, CFI, IFI and NFI indices are goodness of fit indices, CFI is Adaptive Fit Index, IFI Incremental Fit Index and NFI Normal Fit Index. It is advisable to have values greater than 0.9. The closer they are to 1 indicates that the fitted model is a good fit. Since the values of CFI (0.912), IFI (0.908) and NFI (0.923) are higher than 0.9 , this indicates that the model is appropriate. The PCFI index is the fit index, which varies between zero and 1 . If the value of this index is greater than 0.5 , it indicates that the model fit is appropriate. Since the value of PCFI index (0.648) is greater than 0.5 in this study, it shows that the model is suitable. The RMSEA is the second root of the mean squared error estimation, which is expected to be less than 0.08. Since this value is 0.068 in the present study, it indicates the suitability of the model. In general, according to the estimated indices, the fit of the developed model is confirmed.

\section{Discussion}

Instead of considering the importance of entrepreneurial intention as the main condition for updating entrepreneurial behaviors on the one hand, rather than on the role of apprenticeships and entrepreneurial principles as one of the main variables of influence. The purpose of this study was to investigate the impact of internship courses and entrepreneurship fundamentals on the entrepreneurial intention of agricultural students in applied science centers of western Iran. The results of correlation analysis showed that there is a significant relationship between the variables of internship courses and perceived behavioral control, subjective norms, attitude toward behavior and entrepreneurial intention of students. In other words, internships have a significant effect on students' perceived behavioral control, subjective norms, attitude toward behavior and entrepreneurial intention. These results are in line with the study of Moradi \& Delshad (1986) and Reza et al. (2011). On the other hand, the results of correlation analysis showed that there is a significant difference between the variables of entrepreneurship fundamentals and perceived behavioral control, subjective norms, attitude towards behavior and entrepreneurial intention of students. In other words, entrepreneurship fundamentals have a significant effect on perceived behavioral control, subjective norms, attitude toward behavior and entrepreneurial intention of students. 
The findings of this study are in line with the results of the study by Arasti et al. (2011). The result of the study was that, based on its quantifiable attributes, the overall structure of the research model adopted was, in other words, the actual model of the theoretical and theoretical literature. In general, the structural model showed that, in the standard case, the effect of the internship period on attitudes toward behavior was 0.08 , perceived behavioral control was 0.05 , and subjective norms were 0.19 , which was a weak to moderate effect. كه This is a weak to medium effect. On the other hand, in the standard case, the effect of entrepreneurship fundamentals on attitude toward behavior is 0.56 , perceived behavioral control is 0.56 and subjective norms is 0.45 which is a moderate to strong effect. Therefore, according to the findings of the study, entrepreneurship fundamentals have a significant effect on attitude. This finding is in agreement with the results of the study by Hawoll \& Faran (2006). The results of the study showed that entrepreneurial education was also instrumental in creating a positive attitude toward the behavior of students who completed entrepreneurial education. The results also showed that the lesson of entrepreneurship fundamentals had a positive and significant effect on students' performance. In the Aegean pattern, the following are the basic paradigms.

On the other hand, the results showed a positive and significant effect of entrepreneurship fundamentals on students' perception of behavioral control. Other studies have also confirmed this hypothesis. The paper (2011) has shown that self-efficacy, which is a prerequisite for empowerment perception, has become more fundamental in students following entrepreneurship training programs. Understandability has been shown to be a significant measure of one's ability to initiate a business and this perception is related to its behavioral control.

According to the results obtained from the structural model of perceived behavioral control variable, there is a positive and significant effect on entrepreneurship intention variable dependency. Therefore, it can be inferred that students who have strong beliefs, perceptions and positive emotions about their abilities need higher entrepreneurship. In this context, the results of Mohseni et al. (2013) research show that people with stronger perceived behavioral control have a higher sense of responsibility and perform assigned tasks better. This finding is also consistent with the results of Adakia \& Ibrahim (2016) and Yaqubi et al. (2015).

\section{Conclusion}

According to the results, the subjective norm variable has a positive and significant effect on the intention-to-creator variable. In fact, subjective norms are the reflection of social pressures that are especially felt to trigger a particular behavior (Zali et al., 2010). Since subjective norms have an important impact on the perception of individuals by their 
entrepreneurial intentions. Therefore, each subjective norm, namely the beliefs and values of the entrepreneur, aligns with the entrepreneurial activity, will have greater motivation and intention to start an entrepreneurial career. The results obtained in this context are consistent with the results of the study of Koushki et al. (2012). Considering the results of this study, it is clear that attitude variable has a positive and significant effect on entrepreneurial intention. In a way, having a positive attitude towards being entrepreneurial or having a good readiness to respond favorably to a decision to choose a career path in the individual will lead to entrepreneurial intention. This result is consistent with the results of the study by Saif et al. (2014).

\section{References}

Adekiya, A., and Ibrahim, F. (2016). Entrepreneurship intention among students: The antecedent role of culture and entrepreneurship training and development. The International Journal of Management Education, 14, 116-132

Ajzen, I. (1991). The theory of planned behaviour. Organizational Behaviour and Human Decision Processes, 50(2), 179-211.

Arasti, Z. Saeid Banaki, S. Imanpour, N. (2011). Teaching "Entrepreneurship Entrepreneurship" in Coding Students to the Top of Management (Case Study: Fuller Literature and Humanities, Third University). Entrepreneurship Development Quarterly, 4(4), 107-124.

Azizi, M. Taheri, M. (2013). The Impact of Entrepreneurship Education on Students' Entrepreneurial Intention and Characteristics. Journal of Innovation and Value Creation, 2 (4).

Badri, A., Liakhtdar, M. A., Abedi, M. R., Jafari, A. (2016). An Investigation of Entrepreneurial Potentials of Isfahan University Students.

Baghersad, Zali, M. R., Razavi, C. M., Said Banadaki, S. (2013). The Impact of Entrepreneurship Training on the Entrepreneurial Intention of Technical and Professional Students. Entrepreneurship Development, 6(4), 21-36.

Farmer, M. (2014). An Investigation of Entrepreneurial Intention of Payam Noor Students and its Affecting Structures. Entrepreneurship Development Quarterly, 7(3), 548-529.

Fayolle, A.; Gailly, B.; Narjisse, L.C. (2006). Effect and counter-effect of entrepreneurship education and social context on student's intentions, Estudios de Economia Aplicada, 24(2), $509-523$.

Gholamreza, P., Zarafshani, K., Mirkadzad, A., Ghorbani Pir Alidehi, F. (2011). Attitudes of trainees towards the role of apprenticeships in employment promotion and agricultural education in the western provinces of Iran. National Conference on Employment of Agricultural and Natural Resources Graduates. 
Habibpour, K. Safari Shali, R. (2011). Comprehensive Guide to the Application of SPSS in Survey Research (Quantitative Data Analysis). Thinkers Publications - Loyeh, Tehran.

Hosseini Nia, Gh. Ataei, P. \& Yaghoubi Ferrani, A. (2017). Evaluation of Entrepreneurial Skills and Characteristics of Students and Their Impact on Entrepreneurship Intention (Case Study: Scientific-Applied Skills Training Centers). Iranian Journal of Engineering Education, 19(73), 25-44.

Hosseini, S. S. (2013). The Role and Influence of Internship and Internship Courses on Developing Entrepreneurial Moods from Students' Viewpoints at Payam Noor Aligoodarz University. National Conference on Valve Training Towards Effective Communication between Industry and University.

Iakovleva, T., Kolvereid, L., \& Stephen, U. (2011). Entrepreneurial intentions in developing and developed countries. Journal of Education \& Training, 53(5), 353-370.

Jacoby Frani, A., Believe, M. \& Karimi, S. (2015). Entrepreneurial Knowledge and Skills in Developing Digital Entrepreneurship for Students at Hamadan State University. Journal of Information Processing and Information Management, 31(3), 785-802.

Julian, A. (2013). Emotional intelligence and entrepreneurial intentions of university students: A case of bachelor of entrepreneurship and small business management students at Makerere University Business School, a master thesis, available at: http://makir.mak.ac.ug/handle/10570/3160 (retrieved October 2016).

Karimi, S. (2015). Investigating the direct, indirect and moderating effects of institutional environment on agricultural students' entrepreneurial intention. Journal of Entrepreneurship Development, 8(2), 371-390.

Karimi, S. Melamirzaei, F. \& Movahedi, R. (2016). The Impact of Entrepreneurship Education and Its Benefits on the Entrepreneurial Intention of Agricultural Students in Western Universities. Journal of Agricultural Education Management Research, 38, 51-65.

Krueger, N. F. Jr., Reilly, M. D., \& Carsrud, A. L. (2000). "Competing models of entrepreneurial intentions". Journal of Business Venturing, 15, 411- 432.

Lee, L., Wang, P. K., Foo, M. D. \& Leung, A. (2011). "Entrepreneurial intentions: The influence of organizational and individual factors". Journal of Business Venturing, 26, 124-136.

Lena, Lee, P. Wong, Maw D. F. \& Aegean, L. (2011). Entrepreneurial intentions: the influence of organizational and individual factors. Journal of Business Venturing, , 26, $124-136$.

Martin, B. C., McNally, J. J., \& Kay, M. J. (2013). Examining the formation of human capital in entrepreneurship: A meta-analysis of entrepreneurship education outcomes. Journal of Business Venturing, 28(2), 211-224. 
Mary, H, H (2017). The Relationship between Carbine and Internship Courses with Employment and Entrepreneurship (Case Study: Graduates of Bandar Lengeh Center for Applied Science). Management and Entrepreneurship Studies, 3(3), 42-60.

Mohseni, A., Mousavi, H. \& Jamali, M. (2013). The role of entrepreneurship education in entrepreneurial attitude and general self-efficacy beliefs of students. Quarterly Journal of Research and Planning in Higher Education, 69, 63-80.

Moradi, H., Bijeni, M., Karami, Gh., And True Falah, n. (2012). Comparative Assessment of Psychological Properties Affecting Entrepreneurial Attitudes in Agricultural Engineering Students (Case Study: Ramin Khuzestan University of Agriculture and Natural Resources). Iranian Journal of Engineering Education, 14 (53), 65-81.

Moriano, J. A. \& Gorgievski, M. (2007). Psychology of entrepreneurship: research and education. Universidad National Education a Distancia (UNED) Madrid.

Peng, Z., Lu, G., \& Kang, H. (2012). Entrepreneurial intentions and its influencing factors: A survey of the university students in Xi'an China. Scientific Research, 3: 95-100.

Qasemi, J. Asadi, A. (2010). Factor Analysis of Factors Affecting Entrepreneurial Mood in Graduate Students: A Case Study of College of Agriculture and Natural Resources, University of Tehran. Journal of Agricultural Economics and Development, 24(1), 1322.

Rahmanian-Koushaki, M., Chizari, M., \& Havasi, A. (2012). Investigating the Factors Affecting the Intention of Entrepreneurship on Agricultural Students of Ilam Azad University, Journal of Entrepreneurship Development, 4(15), 100-110.

Sánchez, J. C. (2011). University training for entrepreneurial competencies: Its impact on intention of venture creation. International Entrepreneurship and Management Journal, 7(3), 239-254.

Shakiba, H. Hejazi, C. \& Hosseini, S. M. (2015). The Relationship between Social Capital and Entrepreneurship Intention in Agricultural Students of Tehran University. Journal of Agricultural Education Management Research, 38, 89-78.

Sharafi, A. (2014). LISREL (Step by Step Training) LISREL, Howar Publishing.

Saif, M. H., Sabet-Maharlawi, A., Rasatgar, A. \& Abadi, A. (2014). Factors Influencing University Entrepreneurship Intention Among Students of Medical Sciences University, 7(15), 85-71.

Shinnar, R. S., Hsu, D. K., \& Powell, B. C. (2014). Self-efficacy, entrepreneurial intentions, and gender: Assessing the impact of entrepreneurship education longitudinally. The International Journal of Management Education, 12, 561-570.

Souitaris, V., Zerbinati, S., \& Al-Laham, A. (2007). Do entrepreneurship programmers raise entrepreneurial intention of science and engineering students? The effect of learning, inspiration and resources. Journal of Business Venturing, 22(4), 566 - 591. 
Taj-Abadi, R. (2008). Entrepreneurship education and development and its application in agricultural higher education. National Entrepreneurship Collection, Cultural and Social Conference, Islamic Azad University, Rouden Campus.

Zali, M., Razavi, S. M., Yadollahi Farsi, J. \& Kurd, A. (2010). Evaluation of Entrepreneurial Situation in Iran. Tehran: Institute of Labor and Social Security publications. 